\title{
SHIFTING NOIR ELEMENTS: AN OVERVIEW ON NOIR FICTION IN SOUTHEAST ASIA
}

\author{
Ririn Kurnia Trisnawati \\ Currently Affiliated with PhD in English Literature \\ Faculty of Arts and Social Sciences \\ Universiti Brunei Darussalam \& \\ Lecturer of Faculty of Humanities \\ Jenderal Soedirman University
}

\begin{abstract}
The emergence of noir fiction in Southeast Asian countries has showcased particular evolvement of noir elements. The noir works produced in this region have embraced shifting noir themes and noir protagonists that slightly move away from what formerly constitutes noir fiction. Thus, this study aims at investigating to what extent these two noir elements from noir fiction produced in Southeast Asia has differed from its preceding noir works in the scholarship of noir genre. As a preliminary finding, this study only highlights the shifting noir elements taken from selected noir stories represented by some noir anthologies produced in Southeast Asia. They are KL Noir from Malaysia, Singapore Noir from Singapore, and Manila Noir from the Philippines. The result shows that noir themes have departed from criminality and violence to some other contextualized themes such as supernaturalism, religion, and colonial legacy. Meanwhile, noir protagonists are portrayed as those who are involved with criminality not only as criminals but also as 'heroes'. Finally, what is discussed in this study is expected to contribute to a larger discussion of fluidity in noir genre, and, also, noir, or darkness, is proven to be derived from various perspectives.
\end{abstract}

Keyword: noir fiction, noir, protagonist, Southeast Asia, theme

\section{Introduction}

In a nutshell, noir fiction is known as a dark and bleak narrative which actually much develops from hard-boiled fiction and film noir. In the early development of noir fiction, some noir essentials, for instance detective characters and femme-fatale, are borrowed and adopted from these two previous genres. Besides, noir, in itself, is a challenging issue since noir is seen as "an unstable and shifting critical category"
(Dussere, 2014, p. 3). This fact implies that noir fiction has possibly been undergoing shifting development from time to time. Thus, this study tries to encapsulate one perspective on how noir fiction performs its shifting category.

In the beginning of the 21st century, there has been a new trend gaining momentum when a new type of noir fiction starts to be recognized. Noir narratives based on geographical settings are mushrooming. This so-called city- 
titled noir fiction is written by employing names of cities, either capital cities or metropolitan ones, around the world which are set as the setting and the title of the noir works. The popularity of citytitled noir fiction was set up by Akashic Books, a Brooklyn-based international publisher whose success is through the publication of anthologies of noir short story. In 2004, Akashic's Brooklyn Noir was the very first city-titled noir series to publish and "it was not only successful, it spawned a lengthy series of similar anthologies set in varied locations" (Davis, 2010, p. 9). At this stage, Brooklyn Noir was trendsetting the evolved noir fiction. To list the current Akashic catalogue, there are forty different volumes including Boston Noir (ed. Dennis Lehane), Havana Noir (ed. Achy Obejas), Miami Noir (ed. Les Standiford), Mexico Noir (ed. Paco Ignacio Taibo), etc. There are some other titles mentioned in Hagedorn such as Baltimore Noir, Boston Noir 1 \&2, D.C. Noir 1 \& 2, Istanbul Noir, London Noir, Moscow Noir, Mumbai Noir, Paris Noir, Rome Noir, Venice Noir (Hagedorn, 2013, p. 3), and more titles are showcased in its website: http://www.akashicbooks.com/. The long list shows that Akashic Books continues its ground-breaking series of original noir anthologies by producing more city-titled noir series. According to J.M. Davis, the extensive list of noir series published by Akashic Books signifies at least two things: firstly, “[people] live in a 'noir' agesceptical, if not cynical, about heroism in particular and greatness in general," and secondly, "the vast literature of noir proves [that] noir is malleable" (Davis, 2010, p. 10). Here, this concludes that there is such growing acceptance and appreciation towards this particular type of noir fiction.

As city-titled noir fiction can be world widely found, they are also reachable in Southeast Asia. In Southeast Asia, publication of city-titled noir series is available to respond the popularity of this genre. Interestingly, the noir anthologies are published not only by Akashic Books, which is considered as international publisher, but also by some other local 
publishers. Akashic Books has expanded its noir series by publishing some in Southeast Asian region namely Manila Noir (ed Jessica Hagedorn) in 2013 and Singapore Noir (ed Cheryl Lu-Lien Tan) in 2014. The two noir anthologies depict Manila and Singapore as urban cities where modernity and criminality can be found, yet they also expose the social conditions of the two cities to portray various angles of these urban cities. Previously, there are also Christopher G. Moore's Bangkok Noir, published in 2011, regarded as the trendsetter of noir fiction in Southeast Asia, and Moore's Phnom Penh Noir in 2012. The list continues with the publication of KL Noir Red, KL Noir White, KL Noir Blue, and KL Noir Yellow in 2013 and 2014. These anthologies of noir from Malaysia successfully illustrate Kuala Lumpur and its dynamics pertaining to social, historical, and political areas. Kuala Lumpur and its complexity are highlighted to show the dark sides of the city. The latest noir fiction published in Southeast Asia in 2016 is Cambodia Noir. These anthologies are published and distributed in Southeast Asia under different publishers. For instance, KL Noir volumes are published by Novo Fixi, and Bangkok Noir is by Heaven Lake Press; both are local publishing companies from the respective countries, Malaysia and Thailand.

Noir fiction from Southeast Asia offers not only dark stories of cities in Southeast Asian region but also various interpretations of what dark stories mean from Southeast Asian noir works. This eventually can help define meanings of noir in the region's context, Southeast Asian context. Narrated in the form of short stories, they present multifaceted noir narratives that are uniquely specific to the Southeast Asian context. Although most of the anthologies share similar elements of noir which are derived from their western counterpart, these noir elements are expressed differently according to their respective urban cities. In regards to the distinctive and multifaceted features presented in noir fiction from Southeast Asia, Eeleen Lee, 
the editor of KL Noir Blue, claims that Kuala Lumpur noir "transcends the literary boundaries" that enables "the work [...] to be free from the weighty realism of Western crime fiction tradition" (Lee, 2014, pp. 9-10). Consequently, in $K L$ Noir, readers will encounter "black magic, the supernatural, and dystopic among these stories-all part of this unique landscape [of Kuala Lumpur]" (ibid). This can be understood that the authors want to showcase the uniqueness of Kuala Lumpur which consequently makes $K L$ Noir depart from the Western noir tradition and establishes a different definition of noir, through the occurrence of black magic, supernaturalism, and other localized issues.

Meanwhile, mentioned in the Introduction of Bangkok Noir, the definition of noir is also similarly perceived that "there is no consensus on the definition of noir that covers all culture [...] it makes writers do not agree on one version of noir" (Moore, 2011, p. ix). Its authors, who are mostly foreigners and few Thais, try to individually interpret the definition of noir which fits Bangkok as an urban city and manifests it in their own versions of noir stories about Bangkok. As a result, Bangkok Noir provides the readers with "a diversity of original voices and perceptions of noiras well as various approaches to tone, structure and characterization" (Moore, 2011, p. x). To this extent, how noir is perceived and demonstrated differently becomes an important notion in this study, and the fact that noir fiction is increasingly popular and spreading across borders emphasizes that the demarcation of noir literature becomes shifted eventually.

Furthermore, the emergence of citytitled noir fiction in Southeast Asia has possibly attracted one follow-up question i.e. how these noir works embrace its shifting characteristic of being noir fiction. In other words, an investigation to probe that these noir works are differently constructed needs to be conducted. Being an under-researched field itself, the scholarship of Southeast Asian noir fiction has become worth exploring, and, thus, 
this study meets its urgency. The field is worth researching in order to investigate to what extent this new type of noir fiction has shifted from the tradition of (western) noir fiction in general. In order to reveal how shifting Southeast Asian noir fiction is, I look into only two noir elements chosen to be scrutinized namely noir theme and noir protagonist. They are chosen as they obviously demonstrate distinctive departure from the western noir tradition. Therefore, this study aims at investigating how noir themes and noir protagonists in city-titled noir fiction from Southeast Asia represented by KL Noir, Singapore Noir and Manila Noir showcase the distinctive peculiarity of noir fiction from Southeast Asia. Also, this study proposes that Southeast Asian noir fiction can be seen as potential noir scholarship to be further explored since this research field presents distinctive uniqueness which departs from the tradition of noir genre in general.

\section{Literature Review}

In order to answer how noir theme and noir protagonist from the three noir anthologies distinctively depart from the noir tradition and eventually embrace shifting noir elements, I begin by exploring how noir fiction is commonly constructed, what noir elements constitute noir fiction in general, and how the discourse of noir theme and noir protagonist has been discussed thus far. In noir studies, there are literary traditions of noir fiction which are mostly developed by western noir literary tradition. These literary traditions constitute the genre and define what noir fiction actually means. Hence, summarized from several resources, noir fiction is commonly defined by the occurrence of these elements: tone, femme-fatale, noir protagonists, and theme.

The first noir element to discuss is tone. Tone constitutes noir fiction, and it is also similarly known as the mood of the noir works. In noir fiction, the tone is "dark cynicism and alienation" (Conard, 2006, p. 10) and "cynical pessimistic mood" (Holt, 2006, p. 24). Here, it can be 
said that tone is the source of why noir fiction is identically associated with noir, or darkness. Thus, tone and mood in noir have been associated with the occurrence of darkness of life and mystery where the word noir is actually derived from. This makes tone and mood the central noir element as they are immediately associated with dark, cynical and alienated stories. In addition, Philip Simpson has extended the meaning of tone and mood in noir fiction by exemplifying further how they shape noir. According to Simpson, as noir fiction is stamped by "its prevailing mood of pessimism and cynicism", it may also address "personal and societal failure, urban paranoia, [and] the individual's disconnection from society" (Simpson, 2010, p. 189). Tone and mood that constitute noir are variously stirred by such circumstances of pessimism and cynicism from both individuals and society bringing failure, paranoia and disconnection inside the noir narratives. In its further development of noir fiction, tone remains to be unchanged and static to paint gloominess in the noir fiction, including in city-titled noir fiction.

The next noir element to discuss is femme-fatale. The deathly female character of femme-fatale is defined as "deceitful women who like to use their sexual allure to mislead the detective" (McCan, p. 53). The existence of femmefatale in noir fiction is maintained from the detective story, and her destructive nature also remains in noir fiction. Her figure may contribute to the downfall of the protagonist, trigger and worsen the crime, and add on the mysterious tone she usually performs in the preceding genre. Being maintained in noir fiction, femmefatale completes the world of darkness narrated in the noir fiction through her actions.

Finally, the last two evolving noir elements are noir protagonist and theme in noir fiction. They are generated from detective stories and hard-boiled crime fiction into a wider coverage of noir, dark stories; consequently, the meaning of darkness is much influenced by what a protagonist does and what theme is 
narrated about. A protagonist in noir fiction undergoes profound evolvement. It starts from the omission of (private) detective characters found previously in detective story and hard-boiled crime fiction, and it is continued by the existence of some protagonists who are not only directly conflicted with crimes but also with other issues. In light of this omission, Bonnie Rhee Andryeyev confirms there is no detective figure in the current American noir texts (Andryeyev, 2012, p. 11). This explains how the absence of detective characters in contemporary noir fiction demonstrates an example of how shifting noir fiction is happening, partly in defining its noir protagonists. Meanwhile, quoting what Guzman-Medrano states that a protagonist of noir fiction is not the main detective per se, but "rather a person who gets involved directly or indirectly in the investigation of a crime because of certain circumstance" (Guzman-Medrano, 2013, p. 29). Thus, to this extent, noir protagonist, as one element of noir fiction, is proven to be actively evolving and shifting in which a noir protagonist is not necessarily a detective protagonist, and noir protagonist can be criminal, victim, and other crime-related characters.

In addition, there are some other important notions embedded in the characterization of noir protagonists. Noir protagonists are characterized as "selfdestructive individuals" (GuzmanMedrano, 2013, p. 15), "alienated and desperate characters [with] betrayals left and right", (Hagedorn, 2013, p. 13), and "morally ambiguous and unquestionably evil [people]" (Holt, 2006, p. 24). These portrayals of noir protagonists add on the dark tone offered in noir fiction where their pessimistic, evil and alienated are blended to darken the works. Also, such characters living in noir fiction portray sentiments of a dark-fatalistic world. Finally, this given explanation shows that noir protagonist functioning as one noir element has its own quality to darken this particular genre, and its development also clearly suggests that noir protagonist does shift and depart from its early pioneering era of noir fiction. 
Theme is another element of noir fiction that has evolved variedly. As noir fiction further develops, Foster Hirsch regards criminality as one factor to determine conventions of noir fiction as an established genre. When Hirsch exemplifies the convention that "noir deals with criminal activity, from variety of perspectives, [and] a general mood of dislocation and bleakness, [...] noir tells its stories in a particular way", his statement intensely justifies that noir fiction is closely linked to criminality (Hirsch, 1981, p. 72). Similarly vocalizing the close association of noir fiction and criminality, Andryeyev states that in noir texts "crime is a way of being, not just a sensational act" (Andryeyev, 2012, p. 11). This is a strong affirmation to accept how criminality is closely attached to noir fiction and to see that criminality as 'the lifestyle of noir fiction' is even acceptable. These statements seemingly remind the audience that noir fiction is formerly established from crime fiction and hardboiled detective fiction, thus the aforementioned definitions emphasize that criminality definitely constitutes noir fiction as its theme.

Additionally, by studying works of other pioneering noir authors such as Cain and Chandler, Smoak Shelby identifies prominent depictions of violence in their works. Shelby confirms that their works continuously have also shown "images of violence", for example, transforming cars from benign machines of transportation to tools with "darker and more devious uses" (Shelby, 2011, pp. 40-41) which signifies the occurrence of violence embodied via cars where cars are employed to gain the images of danger, fatality and death . Here, Shelby confirms that the association of noir fiction with violence has existed during the pioneering era of noir fiction. Meanwhile, reviewing American and British noir, Gary Hoppenstand contends that the thematic qualities of alienation, paranoia, and chaotic violence that were thought to be the sole domain of American noir can also be readily found in British noir fiction (Hoppenstand, 1998, p. 162), thereby showing that the association between noir, criminality and violence is 
not just limited to American noir fiction. Violence in noir fiction has been contagious as it is prevalent in both American and British noir tradition. Thus far, the fact that noir fiction presents crime and violence as its grounding theme is inevitable, yet noir fiction also foregrounds "a form of social criticism to specific social or political system[s]" which include "violence, torture, and death brought by a repressive government system" (Guzman-Medrano, 2013, pp. 2829). This suggests an expanding theme of criminality and violence narrated in noir fiction that noir fiction and its theme on criminality and violence are also employed as a means of social criticism. In other words, criminality and violence in noir fiction are also expanded to vocalize the society disapproval on particular social and political issues.

Finally, how noir elements are born, evolve and constitute noir fiction have been discussed here. They are mostly seen from the perspective western tradition of noir since this scholarship is relatively established and, thus, has been used as reference to look into. In this study, they are taken into account as parameter to see how the two noir elements i.e. noir theme and noir protagonist are employed to constitute city-titled noir anthologies from Southeast Asia. Thus, this study is to question whether these two elements are consistently maintained or they are freely developed to construct noir texts written and set in Southeast Asian cities. Eventually, the study is able to showcase noir fiction that is believed to be fluid and shifting, including the noir works from Southeast Asian region.

\section{Research Methods}

This study is conducted by analysing three anthologies of noir fiction written and set in some cities in Southeast Asia which is later referred as city-titled noir fiction from Southeast Asia. They are Jessica Hagedorn's Manila Noir (2013), Cheryl Lu-Lien Tan's Singapore Noir (2014) and KL Noir series. Additionally, KL Noir series is the only anthology from the region available in 4 volumes namely Amir Muhammad's KL Noir: Red (2013), Amir 
Hafizi's KL Noir: White (2014), Eeleen Lee's KL Noir: Blue (2014), and, the last volume, Kris Williamson's KL Noir: Yellow (2014). Each noir anthology is composed by approximately 10 until 12 short stories. In this study, selection upon the noir short stories under the study is carefully done according to the objective of this study i.e. showcasing how noir theme and noir protagonist have shifted. The first phase is done by reading the three noir anthologies and continued by categorizing the short stories where the noir theme and noir protagonist are found to be shifting. The next phase is to analyse the chosen noir short stories where the shifting noir elements are prevalent. Taking the data from the chosen literary text, thus, this study is categorized as a qualitative-based research in which the data are qualitatively interpreted and analysed in order to meet the objective of this study.

Due to certain limitation, this study is only to present a preliminary result of the analysis which means the result is presented based on selected noir short stories. In order to showcase the shifting noir themes in city-titled noir fiction from Southeast Asia, represented by three anthologies, there are seven noir short stories examined. They are Dayang Noor's “The Machete and me", Amir Hafizi's "The Unbeliever", Preeta Samarasan's "Rukun Tetangga" taken from KL Noir: Red. Next, M. Shanmughalingam's "Flowers for KK" is taken from KL Noir: White. Rosario Cruz Lucero's "A Human Right" from Manila Noir and Damon Chua's "Saiful and the Pink Edward VII" of Singapore Noir are also selected to portray the shifting noir theme presented in the noir anthologies from Southeast Asia. Meanwhile, Megat Ishak's "Cannibal Vs Ah Long” from $K L$ Noir: Red, Hadi M Nor's "Breadwinner" from KL Noir: White and Rozlan Mohd Noor's "Ballerina in Pink" from KL Noir: Blue are analysed in order to show that the shifting noir protagonist is prevalent from the noir works. Finally, this study methodologically adopts the established noir studies, mostly referred from western noir tradition, that has been discussed in the previous section as its parameter to 
investigate to what extent noir element and noir protagonist found in Southeast Asian noir fiction have moved away from the noir tradition.

\section{Result and Discussion}

A. Noir Theme in City-Titled Noir Fiction from Southeast Asia: Beyond Criminality and Violence

As mentioned in Literature Review, noir fiction is strongly associated with darkness and gloominess in which criminality and violence are claimed to be the source that constitutes the noir in noir fiction. Several studies have previously conveyed that criminality and violence are seen as the central theme of noir fiction. However, what is found in this study may prove that noir and its shifting category are inevitable prevailing. In this study of three noir anthologies representing noir fiction from Southeast Asia, noir themes cover issues of criminality and violence, yet they also include some other themes moving away from criminality and violence. Therefore, I argue the noir themes are proven to be beyond criminality and violence as supernaturalism, religion and colonial legacy can be simultaneously found to be the themes. This means supernaturalism, religion and colonial legacy can be said as the shifting point that noir themes are not solely about criminality and violence.

As noir fiction is, of course, all about bleakness and darkness, these grand tone and mood of noir fiction are highlighted and achieved by employing various perspectives. One of them is by employing supernaturalism inserted as the noir theme. Here, some noir authors from these anthologies utilize supernaturalism as a source of darkness that makes the short stories noir. The dark side of supernaturalism in Dayang Noor's “The Machete and me" and Amir Hafizi's "The Unbeliever" is manifested through the supernatural beings. The supernatural beings are portrayed as haunting, deathly, and powerful creatures. In Noor's "The Machete and me", the sacred and antique machete is mystically possessed, and it slaughters the whole family members. The 
atmosphere and the scene are her and to prove that she does exist. They mysteriously dreadful that they darken are obsessed to prove what they believe and spread the horror of the noir short by underestimating the local wisdom story. Further, the absence of criminality in this noir story can be seen that criminality is not the only scene to create the bleakness of the story as supernaturalism can also do it.

Similarly, what is found in Hafizi's "The Unbeliever" suggests that supernaturalism becomes the main theme of this noir narrative. The dark and bleak tone of the noir work is revealed through the supernatural being namely Nyi Roro Kidul. The entity of Nyi Roro Kidul who appears during the summoning and is described by the protagonist, the unnamed-narrator, is described as "impossibly huge, slightly humanoid but of its form were all wrong", and the deity is then described as "distinctively feminine" and "towered over everything, and wore the clouds as it would a sarong" (Hafizi, 2013, p. 256). Here, her existence triggers the conflict of the noir story where some American researchers want to summon where Nyi Roro Kidul is well-known due to her magical power. Consequently, after summoning ritual is done, these American researchers face their fatal casualty: death and mental breakdown. Nyi Roro Kidul and her invisible power are portrayed superstitiously strong as it is mentioned that "all enemies would die before her waves and currents" (Hafizi, 2013, p. 250). Her mystical power is proven, and she wins over her 'enemies' referring to those who demeaning her existence as the queen of the sea.

Based on the two aforementioned noir stories above, supernaturalism is clearly employed as the theme of the noir works, and, thus it can also be seen that the noir theme moves away from issues of criminality. The dark sides of the noir story revolve around the supernaturalism and its supernatural beings i.e. sacredly possessed machete and Nyi Roro Kidul. The fact that supernaturalism and its 
supernatural beings become the shifting noir theme is in line with how supernatural beings are commonly seen in the study of Southeast Asian folklore. Supernatural beings are identified as "disciplinary apparatus [...] to create fear and warn the community" (Laranjo, Martinez-Erbite, \& Santos, 2013, p. 23). This can be related that inserting supernaturalism in noir works is, thus, to construct fear and distress which later can become bleakness and darkness of the story. Thus, criminality is not the only theme that can darken the noir works as it is eventually proven that supernaturalism can do it.

Another shifting noir theme captured within the noir anthologies from Southeast Asian noir fiction is exemplified by Shanmughalingam's "Flowers for KK". The work highlights the issue of religion as the source of the bleakness and alienation of the noir stories. Here, religion is employed by noir authors to spread the ultimate message that the manipulation of religion practice can terrify and darken lives of its beholders. Shanmughalingam's "Flower for KK" is a noir story that explores religion as its theme and demonstrates religion as a means of Othering. The fact that "religions are famous for making distinctions between 'us' and 'them'" becomes the starting point to argue that religion also becomes an important notion to constitute noir in this work (Kim, 2016, p. 260). Here, the noir work focuses more on how Hinduism can create this binary powerrelation among Hindu women and men, and when it is manipulated, it belittles and disadvantages the Hindu women's position. Accordingly, as it is narrated in this particular noir story, it makes Indra subordinately live under her husband's dominance which is, unfortunately, reinforced by the marriage custom in Hinduism.

Furthermore, criminality is notified absent in this noir story, so is violence. What is highlighted in this noir story rather is more on how religion and its tradition are imposed on Indra, the Hindu 
wife protagonist, and making her to be submissive and despairing. Religion and its manipulation are the sources where the darkness and bleakness of the story are derived from. Indra and how religion treats her become the centre of the noir story. Her life under her husband's manipulation of religion teachings is spotted as one important issue to state the noir of this noir narrative. The distinction of 'us and them' caused by religion is intensively narrated to show how the noir theme is about the religion, and, thus, it constructs the meaning of noir. Some instances are found when Indra must bear herself when her husband chooses to marry her own sister since Indra has been living as a childless wife. When Indra eventually gives birth to Kumari, Indra's baby girl, she is continuously treated unfairly as “[her husband] hadn't lifted her up anywhere as high and he had embraced [Indra] with less warmth" (Shanmughalingam, 2013, p. 80). This is because distinction between 'us and them' in Hinduism which is based on a social system that values male descendants more than female ones. The difference between a baby boy and a baby girl instigates a huge gap of power-relation among Hindu wives.

The last shifting noir theme is found in Preeta Samarasan's "Rukun Tetangga", Rosario Cruz Lucero's "A Human Right", Damon Chua's "Saiful and the Pink Edward VII". These noir works vocalize the issue of colonial legacy from the respective countries e.g. Malaysia, Singapore and the Philippines. Colonial legacy is employed to show darkness and bleakness caused by colonialism. Further, the inclusion of colonial legacy as a noir theme found in Southeast Asian noir fiction can be seen as an expression of scar of colonialism, and, this scar is, somehow, perpetuated during the postcolonial era manifested through the colonial legacy. Noir fiction which is identically narrated with gloominess is used as an appropriate channel to express the dark sides of colonialism as well as the colonial legacy. Additionally, inserting colonial legacy in these noir narratives of Malaysia, 
Singapore and the Philippines emphasizes that these three countries share similar historical background on colonialism, and they may endure a similar scar of colonialism that is expressed through works of noir, accordingly. This is in line with what Rajeev Patke and Philip Holden explain that these three countries have the commonality of "shared historical dimension from colonial to contemporary history" (Patke \& Holden, 2010, p. 1). Thus, this shared historical dimension of colonialism is well-expressed in noir works, and it also can be contagiously found in some noir stories from Southeast Asia.

In Preeta Samarasan's "Rukun Tetangga", the noir theme of colonial legacy is particularly about the racial ideology existing in the multiracial society of Malaysia. Racial ideology is understood as "the accounts of making extensive use of racial descriptions and explanations and assigning major causal significance to racial categories, and also utilizes racial evaluation and prescription to a substantial degree" (Reeves, 1983, p. 244). Tracing back the history of colonial Malaya, it is evident that British colonialism has radically fashioned racial ideology across the nation despite merely extracting profit from rubber plantation and tin mining (Hirschman, 1986, p. 357). Consequently, racial ideology is believed to be one of the colonial legacies in the Malaysian society. In the story, Guna Uncle who is a Malaysian-Indian suffers from racial abuse because of his racial identity from Indian ethnicity. This is because of the extensive use of racial description during the colonial domination where Malayan population was based on their "social status, economic factors and ethnic identity" (Holst, 2012, p. 35). As a result, racial ideology is expansively used as racial catalogues or "ethnicised identity" that is still prevalent in present Malaysian society impacting political and social system of the country (Holst, 2012, p. 1).

For instance, Malaysia has been practicing categorization of identities in which the official categories are divided 
into the three races. This categorization is called MCIO-Malay, Chinese, Indian and Other-where it is through "their MCIO identities that Malaysians are required to call up every time [...] in a variety of administrative forms such as the state censes, university applications, medical records, and police report forms." (Gabriel, 2015 , p. 2). Accordingly, based on this rank, Guna Uncle is seen as the lowest ethnicity in Malaysian society that other ethnicities think that they can disregard Guna Uncle by calling him "so sweaty! So sweaty! Keling Kwai, Keling Kwai, don't touch us!" (Samarasan, 2013, p. 55). The word Keling Kwai addressed to Guna Uncle reflects how he is attacked by this derogatory term. According to Selvaraj Velayutham, the term keling and its derivations such as keling-kia and keling kwai, which mean devil or ghost, have taken on negative connotations, and Indians mostly find the label offensive (Velayutham, 2009, p. 263). Calling Indians keling is believed to be "a form of intimidation and a symbolic weapon by non-Indians to reproduce racial and cultural discrimination" (ibid). Guna Uncle's Indian attribute is being excessively used to racially abuse him deliberately. Here, racial ideology indoctrinated during the colonial era has been subscribed and triggers racial discrimination in the postcolonial era. Racial ideology as a colonial legacy is portrayed as the scar of colonialism in the postcolonial era which can cause certain bleakness for certain members of the society.

Meanwhile, Damon Chua's “Saiful and the Pink Edward VII" of Singapore Noir and Rosario Cruz Lucero's “A Human Right" of Manila Noir also present colonial legacy as their noir theme. The former highlights racial ideology as source of the darkness whereas the latter lingers around the issue of injustice experienced in the postcolonial era of the Philippines, particularly happening in the state of Davao. Slightly different from Preeta Samarasan's "Rukun Tetangga" where criminality functions only as the backdrop 
of the story, these two noir narratives employ criminality as their issues.

Saiful's life revolves around his family heirloom, a postage stamp with "a rare Straits Settlement misprint from 1902 featuring a pink-coloured King Edward VII" (Damon, 2014, p. 185). This old postage stamp drags his life into such a complicated trouble since he has promised his late deathbed mother that he would keep this stamp "at any cost" (ibid). Saiful, a Singaporean-Malay, whose precious stamp is stolen by a stamp-broker eventually commits murder and runs away from Singapore to Johor Baru. Here, Saiful's precious stamp symbolizes the material colonial legacy left by the British colonialism that he must struggle at any cost, including murdering the broker. The stamp seems to 'control' Saiful and forces him to illegally migrate to Malaysia. However, during his struggle to get his stamp back, Saiful has also contemplated how his life as Singaporean-Malay is not worthy as he belongs to the non-favoured citizens, the Malay in Singapore. Thus, in the end, his willingness gets stronger to leave Singapore and migrate to Malaysia where he thinks he should belong to.

Simultaneously, there are two issues of colonial legacy found in this work e.g. the stamp as the material colonial legacy and the racial ideology where, oppositely happens in Malaysia, Malay ethnicity is differently treated in Singapore. To this extent, issues of colonial legacy are chosen to be included in noir narratives, and in this study, I argue that colonial legacy is claimed to be one shifting noir theme in noir fiction from Southeast Asia. Colonial legacy becomes the shifting noir theme because this theme has directed the noir works to move away from the dominant issues of criminality and violence that are usually overwhelming in western noir fiction tradition. Instead, these noir fiction offers possibilities that historical background on colonialism and the colonial legacy can be a noir factor in Southeast Asian noir fiction. 
As a conclusion, the abovementioned noir short stories embrace their noir themes that are shown to be shifting and moving away from criminality and violence. Supernaturalism, religion and colonial legacy are the shifting noir themes found that showcase the sources of the tone and mood of noir fiction i.e. bleak, gloomy, and dark. In these noir narratives, each shifting noir element plays their important part to darken, to show cynicism and to show fear that usually constitutes noir works. Thus, it also shows that sources of noir are expanded, and noir fiction from Southeast Asia has shown this expansion.

B. Noir Protagonists in City-Titled Noir Fiction from Southeast Asia: From Criminals to Heroes

In the scholarship of noir studies, noir protagonist has experienced extensive evolvement. The evolvement starts when the character of detective in the pioneering noir writing is omitted and is transformed into characters whose detecting characteristics are seen more important, yet they are not necessarily detective characters. As mentioned previously, the discourse of noir protagonist nowadays is mostly centered on the embedded characterization of being alienated, self-destructive, morally ambiguous and unquestionably evil characters. These characterizations essentially shape the noir protagonist; consequently, the noir protagonist can be any figures of characters as long as they are endowed with such characterizations. This suggests that noir protagonists variously can be criminals, police officers, lay-people, or any common citizens. Therefore, in this study I propose that there is a particular shifting notion performed by noir protagonists in noir fiction from the three countries. The portrayal of shifting noir protagonist is found through the occurrence of various noir protagonists, and one of them is a shift from criminals to heroes. Shifting noir protagonists are found in some noir short stories e.g. Megat Ishak's “Cannibal Vs Ah Long" from KL Noir: Red, Hadi M Nor's "Breadwinner" from KL Noir: White 
and Rozlan Mohd Noor's "Ballerina in Pink" from KL Noir: Blue.

As the title suggests, the noir protagonist of Ishak's "Cannibal Vs Ah Long" is an unnamed cannibal who is ironically described as the 'smiling man'. While he smiles, he slaughters these people involved in illegal loan sharking business to feed his hunger over the human flesh. His main reason of choosing their flesh is "what better source of food than a group of people who would never be missed by society, or even by their own family?" (Ishak, 2013, p. 208). This implies that these people are executed because they are unwanted considering what they have done in their business. These illegal loaners look so much helpful by lending the money, yet they are deceitfully sucking the money from these borrowers. Their existence is parasite, a money sucker; they may ruin more people in the society; therefore, they deserve to be wiped out. They deserve death.

Based on how noir protagonist is defined so far, the smiling man embraces the characterization of being noir protagonist as he is alienated and unquestionably evil. Simultaneously, from him, the shifting noir protagonist can also be identified. The smiling man operates his hunt over these people's flesh by himself showing that his detecting skill is sufficient. However, the fact that "when alone, the smiling man did not smile" suggests how he is seriously concerned with eradicating the illegal moneylending business in Kuala Lumpur (Ishak, 2013, p. 203). He works alone, he seriously gathers the information about these people, and eventually he executes his 'food' by himself, not involving other parties, let alone the authorities. These instances show his alienation within the society. He feels alienated since he seems to disbelieve that the authorities can solve this social problems. He trusts himself only to punish the moneylenders. He does not talk to many people although what he does is actually helping many victimized people who are trapped in this business. 
The fact that the smiling man is obviously and undeniably evil can be seen from the way he enjoys his 'food'. He weirdly and smilingly kills his victims, and his smiles imply how creepy the scene is actually. His being unquestionably evil can be seen from the following quotation:

"The smiling man dropped the machete then gripped Machine Gan's wrist; pulling them apart to stop him from covering the open gash. The smiling man opened his mouth to allow the arterial spray to enter. He gulped and grasped as if sucking in the air around him so as not to allow any drop of precious blood to escape" (Ishak, 2013, p. 200).

Here, he chooses the vital organ to start his evil action and continues to enjoy his food until the victim dies. His evil actions are similarly done like how a cannibal targets his victim: blood and flesh are celebrated. The smiling man embraces this characterization of being evil and also violent. His violent characterization is also apparent as "the smiling man was either real handy with a machete or the blade was razor-sharp because pieces of their faces dropped to the floor with relative ease" (Ishak, 2013, p. 202). His violent image is supported by the use of machete and blade; thus, these two weapons strengthen the tone of violence from this noir short story. To this extent, the smiling man demonstrates his characterization as a noir protagonist through his being evil, alienated and also violent.

However, at the same time, the smiling man also encapsulates the sense of being a hero here. He acts like the punisher in order to terrorize the people working in this industry, and eventually he manages to influence them to reregulate the ways they run the illegal business. At last, the smiling man also gives a hint that he will come back to execute and enjoy the people's blood and flesh as "he was already planning his next feeding. He considered the group of people who would best feed him. Other illegal moneylenders? Lying politicians? Child abusers?" (Ishak, 2013, p. 209). His next targets are those who are harmful in the society. They may create social problems 
and chaos. The smiling man wants to target them, to punish them, and to make them his 'food'. The way he decides his targets implies that by slaughtering these people he is also saving other people, the victims of loan sharking business, dirty politics, and child abuses. His actions may cause death, yet the death of his victims may save other people in the society. This is how the shifting noir protagonist is concluded from. The smiling man who is evil and criminal, since he murders and sucks their blood and flesh, can actually be seen as an anonymous hero after knowing that his victims are actually the unwanted people in the society.

The noir protagonist from Nor's "Breadwinner" also exemplifies this shifting. Ayah, means father, the breadwinner of the family, is the noir protagonist whose work is unidentifiable by his family members as his son mentions that "Ayah's job is a bit of a mystery to me. I'm sure that he's more than just a driver" (Nor, 2013, p. 233). The mystery is accidently revealed until his son confirms himself that his Ayah is more than just a driver when he helps his father to carry "a man lying motionless in a pool of blood" and eventually he witnesses how his father kills the man as he "pushed the hand away and wrapped his hands around the man's throat" (Nor, 2013, p. 234). The figure of the criminal father is overshadowed by his nurturing characteristic as he is the breadwinner of the family as his son acknowledges that "Ayah was rarely present in our lives. But we have food on our plates. And that's all that matters" (Nor, 2013, p. 237). The son who has seen that his father is involved in the murdering seems to ignore what his father has done. The image of a father as the caring father, the hero of the family that provides the family food is considered more important. Thus, this noir protagonist plays a role as both the criminal and the hero of the family. To this extent, this is how the shifting of the noir protagonist is apparent in this noir story. Here, there is a coined-side of criminal figure that the work is trying to show. A 
criminal may also have their heroic figure, even it is only a hero of the family.

The last instance of shifting noir protagonist can be derived from the work of Noor's "Ballerina in Pink". Similarly found in the previously discussed noir stories, the shifting from criminal to hero is also recurrent. The noir protagonist is Kenny Liam, a father of a raped-daughter, who wants to punish the bribed police officer, Assistant Superintendent of Police (ASP) Ahmad Zahid Hamid who "loves the money. Only money" that is why he priorities accepting the bribe rather than enforcing the law (Noor, 2014, p. 34). Zahid sets the rapists and the murders of his daughter out of the prison after he receives "two hundred and fifty thousand" in return (Noor, 2014, p. 31). This amount of money is the proof that Zahid is a greedy police officer that sacrifices his own sworn duty and vows to worship injustice.

The shifting noir protagonist is shown when Liam is both a murderer and a hero for his belated daughter. There is an underlying reason for his to commit the murder. Liam, who works alone, is endowed with sufficient detecting skills. To trap his target, Liam lures Zahid by offering him some money to help his case. Liam manages to operate his revenge by kidnapping Zahid, asking him to acknowledge what he has done, and killing him by injecting the Neuromuscular Blocking agent into Zahid's neck. Liam takes his revenge over his dead daughter. Clearly, what Liam has done makes him fit into the character of noir protagonist that he is a criminal. The fact that he kidnaps and kills a police officer is a criminal conduct that is against the law. However, considering the reason behind killing Zahid, Liam is actually trying to reveal the truth about his daughter's death which is because of Zahid's greediness. He wants to be the hero of his late daughter, his pink ballerina, by revealing the sickening truth behind his daughter's death and the people responsible behind her death. Besides, Liam is also struggling the rights of people in general to fight against the corrupted police officers in Kuala Lumpur 
as the authority like Zahid just "[continues] flooding our streets with the poisons. Kill our children, destroy our families ... our nation" (Noor, 2014, p. 33). The notion of wider impact of what Zahid has done is implicitly mentioned here. Bribing a police officer and disregarding the law enforcement may ruin the nation in the future if it is not stopped. This can be said that Liam is actually fighting not only for his daughter but also for a larger society. Thus, based on what Liam commits, Liam is both a criminal and, simultaneously, a hero for her daughter. To this extent, Liam's character represents a change that is commonly associated with a noir protagonist, a criminal. Here, he is not only committing crime for the sake of the crime itself but also murdering Zahid for the sake of condemning his action of receiving the bribe and fighting for her late daughter.

Finally, the abovementioned short stories have shown that their noir protagonists embrace a particular shifting manner. They embody characterizations of noir protagonists, yet they also move away from the discourse of what a noir protagonist is about. They move from not only a mere criminal but also a hero. They commit criminality, yet by doing so they also vocalize their heroism in a sense that they struggle, fight and protect the people around these noir protagonists.

\section{Conclusion}

The fact that noir elements are shifting is found after investigating citytitled noir short stories from Southeast Asia represented by Singapore Noir, Manila Noir and KL Noir. Two noir elements namely noir theme and noir protagonist demonstrate a shifting manner from the discourse that is associated with them. Aside from criminality and violence, these noir works show some other noir themes such as supernaturalism, religion, and colonial legacy. They construct the dark sides of the noir stories. Supernaturalism, religion and colonial legacy are the themes that shade the alienation, gloominess and cynicism that are commonly found in noir 
works. Meanwhile, noir protagonists of these noir short stories also show its shifting manner by moving from criminal characters into characters whose heroism are also prevailing. These noir protagonists have their other side of being hero albeit their crime conducts. Thus, they are not only merely a criminal but also a hero.

Finally, this study has shown that two noir elements from city-titled noir fiction in Southeast Asia are moving away from their tradition. They develop and expand from the issues of criminality, violence, and the sources of the darkness. Additionally, the study can encapsulate and contribute to the noir scholarship that some noir works from Southeast Asian countries demonstrate their fluidity and shifting styles.

\section{References}

Andryeyev, B. R. (2012). Hearts of

Darkness: Race and Urban

Epistemology in American Noir.

Parkway: ProQuest LLC.
Conard, M. T. (2006). The Philosophy of Film Noir. Kentucky: The University Press of Kentucky.

Damon, C. (2014). Saiful and the Pink Edward VII. In C. L.-L. Tan, Singapore Noir (pp. 185-198). Singapore: Monsoon Books.

Davis, J. M. (2010). Down These Mean Streets A Publisher Must Go: The Akashic Books Noir Series. World Literature Today Volume 84, No 6, 9-11.

Dussere, E. (2014). Introduction Unknown Legends. Faulkner Journal Spring 2014, 3-10.

Guzman-Medrano, G. (2013). PostRevolutionary Post-Modernism: Central American Detective Fiction by the Turn of 21st Century. FIU Electronic Theses and Dissertations. Paper 917. Florida: Florida International University FIU Electronic Theses and Dissertations

Hafizi, A. (2013). The Unbeliever. In M. (. Amir, KL Noir: Red (pp. 231-258). Kuala Lumpur: Fixi Novo.

Hagedorn, J. (. (2013). Manila Noir. New York: Akashic Books.

Hirsch, F. (1981). The Dark Side of the Screen: Film Noir. New York: Da Capo Publisher. 
Hirschman, C. (1986). The Making of Race in Colonial Malaya: Political Economy and Racial Ideologi. The Eastern Sociological Society 08848971/86/0102-033081.50, 330-361.

Holst, F. (2012). Ethnicization and Identity Construction in Malaysia. New York: Routledge.

Holt, J. (2006). A Darker Shade Realism in Neo-Noir. In M. (. Conard, The Philosophy of Film Noir (pp. 23-40). Kentucky: The University of Kentucky.

Hoppenstand, G. (1998). British Noir: The Crime Fiction of W.W. Jacobs. Journal of Popular Culture 32 (1) , 151-163.

Ishak, M. (2013). Cannibal Vs Ah Long. In A. Muhammad, KL Noir: Red (pp. 199 - 209). Kuala Lumpur : Fixi Novo.

Kim, G. J.-S. (2016). Hybridity, Postcolonialism and Asian American Women. Feminist Theology, Vol 24(3) , 260-274.

Laranjo, R., Martinez-Erbite, \& Santos, Z. J. (2013). Intersection of Asian Supernatural Beings in Asian Folk Literature: A Pan-Asian Identity. The Asian Conference on Asian Studies (pp. 15-24). Osaka, Japan: iafor: the International Academic Forum .
Lee, E. (. (2014). KL Noir: Blue. Kuala Lumpur: Fixi Novo.

McCan, S. (n.d.). The Hard-boiled Novel.

Moore, C. G. (2011). Bangkok Noir. Bangkok: Heaven Lake Press.

Noor, R. M. (2014). Ballerina in Pink. In E. Lee, KL Noir: Blue (pp. 15-36). Kuala Lumpur: Fixi Novo.

Nor, H. M. (2013). Breadwinner. In A. Hafizi, KL Noir: White (pp. 233 237). Kuala Lumpur: Fixi Novo.

Patke, R. S., \& Holden, P. (2010). The Routledge Concise History of Southeast Asian Writing in English. London: Routledge .

Reeves, F. (1983). British Racial Discourse. Cambridge: Cambridge University Press.

Samarasan, P. (2013). Rukun Tetangga. In A. Muhammad, KL Noir: Red (pp. 41-56). Kuala Lumpur: Fixi Novo.

Shanmughalingam, M. (2013). Flowers for KK. In A. Hafizi, KL Noir: White (pp. 67-84). Kuala Lumpur: Fixi Novo.

Shelby, S. (2011). Tails, Gunfights, and Murder: The Role of the Automobile in the Noir Fiction of James M. Cain and Raymond Chandler. Clues: A Journal of Detection, 40-46.

Simpson, P. (2010). Noir and the Psycho Thriller. In C. \&. Rzepka, $A$ 
Companion to Crime Fiction (pp.

187-197). West Sussex: Willey-

Blackwell.

Velayutham, S. (2009). Everyday Racism in Singapore. In A. Wise, \& S.

Velayutham, Everyday

Multiculturalism (pp. 225-273).

London: Palgrave Macmillan. 